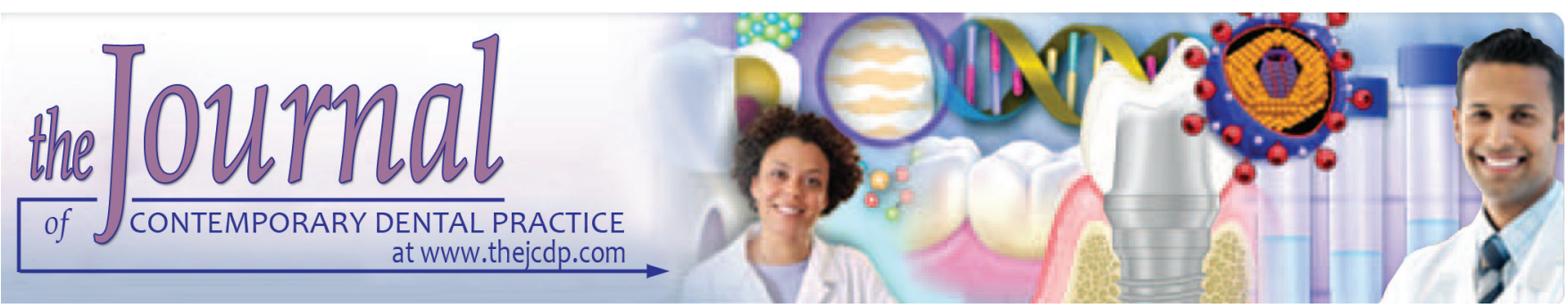

\title{
Pain and Tissue Damage in Response to Orthodontic Tooth Movement: Are They Correlated?
}

\author{
${ }^{1}$ Osmar A Cuoghi, ${ }^{2}$ Francielle Topolski, ${ }^{3}$ Lorraine P de Faria, ${ }^{4}$ Marcos R de Mendonça
}

\begin{abstract}
Aim: To evaluate the correlation between pain and tissue damage in response to orthodontic tooth movement (OTM), such as hyalinization and external apical root resorption (EARR).

Materials and methods: The literature review was used as a methodological strategy, following the knowledge development process - constructivist (ProKnow-C). Study axes were defined and keywords that best represented each axis were selected. The terms were submitted to an adherence test and validation, resulting in 12 keyword combinations. Searches were carried out in the most representative databases for the selected terms, without restriction as for language or publication dates. Retrieved studies were filtered using the EndNote X6 program and classified according to analysis of title, abstract, and keywords. The final portfolio of articles was submitted to bibliometric and systematic analysis.
\end{abstract}

Results: A total of 1,091 studies were retrieved, out of which 719 were repeated and 335 were removed in the classification stage. A total of 37 articles remained in the final portfolio. Only one article was in line with the purpose of this study, indicating absence of correlation between pain and EARR in response to OTM.

\footnotetext{
${ }^{1,4}$ Department of Pediatric and Community Dentistry, Dental School of Araçatuba, Univ Estadual Paulista - UNESP (São Paulo State University), Araçatuba, São Paulo, Brazil

${ }^{2}$ Department of Orthodontics, Dental School of Araçatuba Univ Estadual Paulista - UNESP (São Paulo State University) Araçatuba, São Paulo, Brazil; Faculdade de Odontologia de Araçatuba, Departamento de Odontologia Infantil e Social Disciplina de Ortodontia Preventiva - UNESP, Araçatuba, São Paulo, Brazil

${ }^{3}$ Department of Orthodontics, Dental School of Araçatuba Univ Estadual Paulista - UNESP (São Paulo State University) Araçatuba, São Paulo, Brazil

Corresponding Author: Francielle Topolski, Faculdade de Odontologia de Araçatuba, Departamento de Odontologia Infantil e Social - Disciplina de Ortodontia Preventiva - UNESP Araçatuba, São Paulo, Brazil, Phone: +551836363236, e-mail: frantopolski@gmail.com
}

Conclusion: Further studies are necessary to confirm whether orthodontic pain might serve as a criterion for the use of appropriate mechanical forces, contributing to minimize tissue damage following OTM.

Clinical significance: This article presents a systematic literature review, in which scientific evidence of the correlation between pain and tissue damage during orthodontic movement was studied, providing a scientific answer for the following question: Is pain reported by patients associated with application of inappropriate orthodontic force? Thus, it aims at aiding the orthodontist in the definition of clinical parameters for the use of optimal orthodontic force.

Keywords: Hyalinization, Pain, Root resorption.

How to cite this article: Cuoghi OA, Topolski F, de Faria LP, de Mendonça MR. Pain and Tissue Damage in Response to Orthodontic Tooth Movement: Are They Correlated? J Contemp Dent Pract 2016;17(9):713-720.

Source of support: This work was supported by a Brazilian research funding agency (CAPES).

Conflict of interest: None

\section{INTRODUCTION}

Orthodontic tooth movement (OTM) is a result of the application of mechanical forces to the teeth. Orthodontic forces represent mechanical stimuli that trigger a series of tissue reactions in the periodontal ligament and alveolar bone. These reactions result in alveolar remodeling by resorption and bone apposition processes, allowing tooth displacement. ${ }^{1}$ However, this process is often followed by unwanted tissue damage, mainly the formation of hyalinization areas in the periodontal ligament and the incidence of external apical root resorption (EARR). ${ }^{2}$ Such unwanted tissue damage is related to the application of a biologically inappropriate force system, due to intensity, duration, or distribution. ${ }^{1,3-5}$

The use of biologically compatible mechanical forces is a great challenge to orthodontic treatment. Besides the subjectivity inherent in the concept of ideal mechanical 
force and individual variability, the absence of tools that allow measuring the intensity of force applied to different root regions should be emphasized. ${ }^{1,6}$

One of the clinical observations that can be made during orthodontic treatment is the patient report on the perception of pain. Pain associated with OTM results from mechanical stimulus and from the inflammatory reaction to tensile and compressive stress in the periodontal ligament. ${ }^{7}$ It is questioned, however, whether pain in response to OTM is associated with the application of inappropriate mechanical forces and, consequently, to the incidence of unwanted tissue damage. Thus, the aim of this study was to evaluate the correlation between pain and tissue damage in response to OTM, such as hyalinization and EARR, through literature database analysis. The results may allow the use of patient self-reported pain as clinical criterion to collaborate in the determination of appropriate orthodontic mechanical force, avoiding the incidence of tissue damage associated with orthodontic treatment.

\section{MATERIALS AND METHODS}

The methodological procedures used in this study followed the knowledge development process - constructivist (ProKnow-C). ${ }^{8}$ The study was carried out in February and March 2015, according to the stages illustrated in Figure 1.

Firstly, three study axes were defined: OTM (group I), orthodontic pain (group II), and unwanted tissue damage in response to OTM (group III). After the detailed study of these themes, keywords to be included in each group were defined. Three keyword categories were included in group I, two in group II, and two in group III. Following the definition of keywords, possible synonyms and derivations were also considered. The terms were submitted to an adherence test, which consists of the evaluation of the feedback each keyword produced when searched in databases. The adherence test allowed checking the

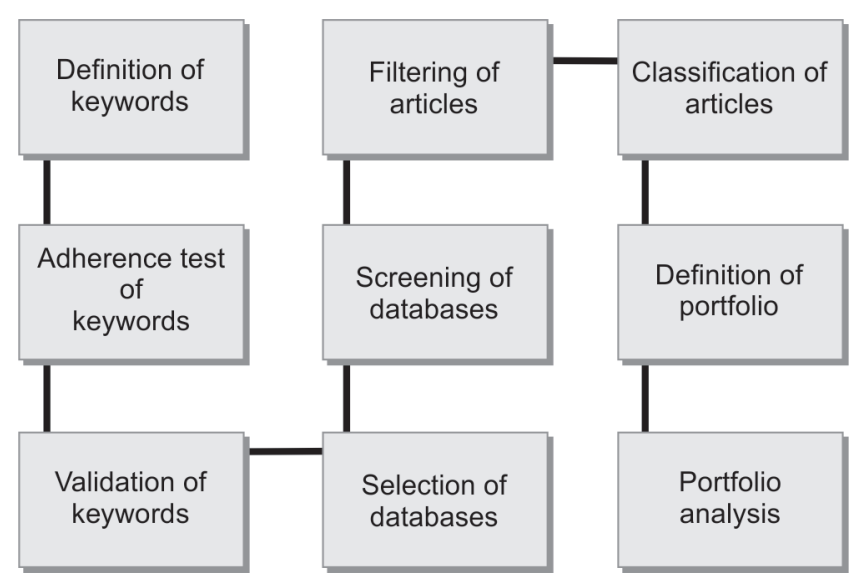

Fig. 1: Methodological stages importance of each keyword, deleting those without much representativeness. The literature databases used for the adherence test were Google scholar and CAPES portal of journals. The latter is the Brazilian national electronic library consortium for science and technology. The keywords included in each category of each group, with their synonyms and derivations, as well as adherence test results for groups I, II, and III are shown in Tables 1 to 3 respectively.

Table 1: Adherence test group I

\begin{tabular}{|c|c|c|c|c|c|}
\hline Category & Keyword & $\begin{array}{l}\text { CAPES } \\
\text { journals }\end{array}$ & $R \%$ * & $\begin{array}{l}\text { Google } \\
\text { Scholar }\end{array}$ & $R \%$ * \\
\hline & $\begin{array}{l}\text { "orthodontic } \\
\text { movement" }\end{array}$ & 0.515 & 0.20 & 5.000 & 0.70 \\
\hline \multirow[t]{3}{*}{1} & $\begin{array}{l}\text { "orthodontic } \\
\text { treatment" }\end{array}$ & 36.513 & 16.80 & 97.700 & 14.00 \\
\hline & Orthodontics & 52.534 & 24.30 & 210.000 & 32.90 \\
\hline & orthodontic* & 101.639 & 46.70 & 289.000 & 46.50 \\
\hline \multirow[t]{2}{*}{2} & $\begin{array}{l}\text { "tooth } \\
\text { movement" }\end{array}$ & 6.203 & 2.90 & 32.500 & 5.00 \\
\hline & $\begin{array}{l}\text { "teeth } \\
\text { movement" }\end{array}$ & 14.550 & 5.00 & 1.190 & 0.20 \\
\hline \multirow[t]{3}{*}{3} & $\begin{array}{l}\text { "tooth } \\
\text { displacement" }\end{array}$ & 4.533 & 2.20 & 3.250 & 0.50 \\
\hline & $\begin{array}{l}\text { "displacement } \\
\text { of teeth" }\end{array}$ & 4.268 & 1.90 & 1.410 & 0.20 \\
\hline & Total & 209.094 & 100.00 & 666.450 & 100.00 \\
\hline
\end{tabular}

${ }^{*}$ Percentage representativeness

Table 2: Adherence test group II

\begin{tabular}{llllll}
\hline & & CAPES & & Google & \\
Category & Keyword & Journals & $R \%{ }^{*}$ & scholar & $R \%^{*}$ \\
\hline 1 & "pain" & 888.281 & 94.60 & 3.050 .000 & 78.30 \\
2 & discomfort & 50.317 & 5.40 & 0.848 .000 & 21.70 \\
\hline & Total & 938.598 & 100.00 & 3.898 .000 & 100.00 \\
\hline
\end{tabular}

*Percentage representativeness

Table 3: Adherence test group III

\begin{tabular}{llllll}
\hline \multirow{2}{*}{ Category } & Keyword & $\begin{array}{l}\text { CAPES } \\
\text { journals }\end{array}$ & $R^{*}{ }^{*}$ & $\begin{array}{l}\text { Google } \\
\text { scholar }\end{array}$ & $R \%^{*}$ \\
\hline 1 & hyalinization & 1.319 & 1.08 & 24.500 & 29.26 \\
& "hyalinized areas" & 0.33 & 0.03 & 0.609 & 0.73 \\
& "hyalinized area" & 0.14 & 0.01 & 0.216 & 0.26 \\
& "hyalinized zones" & 0.4 & 0 & 0.239 & 0.29 \\
& "hyalinized zone" & 0.12 & 0.01 & 0.280 & 0.33 \\
& "hyalinized tissue" & 0.51 & 0.04 & 0.743 & 0.89 \\
& "hyaline areas" & 0.145 & 0.12 & 1.190 & 1.42 \\
& "hyaline area" & 0.133 & 0.11 & 1.740 & 2.08 \\
& "hyaline zones" & 0.169 & 0.14 & 0.810 & 0.97 \\
& "hyaline zone" & 0.351 & 0.29 & 1.520 & 1.82 \\
& "hyaline tissue" & 0.304 & 0.25 & 1.360 & 1.62 \\
& hyalin* & 97.029 & 79.40 & 25.700 & 30.69 \\
& "root resorption" & 22.254 & 18.21 & 23.900 & 28.54 \\
& "apical resorption" & 0.383 & 0.31 & 0.927 & 1.11 \\
\hline Total & 122.201 & 100.0 & 83.734 & 100.0
\end{tabular}

*Percentage representativeness 
Following analysis of the adherence test in group I, all terms from category 1 were replaced by the term orthodontic, followed by $\left(^{*}\right)$. This truncation tool allows the retrieval of the word root, as well as its variations by different suffixes. Thus, by using a simple study method, all category 1 terms in group I would be retrieved. The terms "tooth displacement" and "displacement of teeth" were removed due to low representativeness.

Terms widely used in the orthodontic literature were included in group II to refer to pain in response to OTM. These terms are broad enough and produced a significant number of feedbacks in the databases. In addition, the literature is quite specific as for their use, and the use of derivations or synonyms was not found in the studied context. Therefore, it was not considered necessary to include other terms to represent them.

In group III, category 1 , the term hyalin followed by $\left(^{*}\right)$ was selected in substitution of all other derivations. In category 2, the term "apical resorption" was removed due to low representativeness.

After the adherence test, keywords were submitted to validation by an experienced investigator in the area. Table 4 shows the final set of keywords selected for each group. As a result, 12 combinations were created to be searched in databases (permutation: $\mathrm{Pn}=n !$ or $3 \times 2 \times$ $2=12$ ).

The next stage consisted of the selection of databases from tests carried out in the CAPES portal of journals. Boolean searches were performed with keywords and the databases that produced the highest number of retrievals were selected: Scopus, Medline via PubMed, and Web of Science. Following the study of the functioning of the selected bases, the screening process for the 12 keyword combinations was performed. There was no restriction as for language or publication date. The retrieved studies were exported using EndNote X6 program.

Subsequently, studies were filtered using the EndNote X6 tools, aiming at identifying and removing duplicate ones. The following stage consisted of the classification of articles, through analysis of title, abstract, and keywords. As classification criterion, all studies that evaluated pain, hyalinization, and/or EARR in response to OTM were selected. Thus, the final portfolio of articles was defined, which was subjected to bibliometric and systematic

Table 4: Selected keywords

\begin{tabular}{lllll}
\hline Group I & Group II & Group III & Combinations \\
\hline $\begin{array}{l}\text { orthodontic* } \\
\text { "tooth } \\
\text { movement" } \\
\text { "teeth } \\
\text { movement" }\end{array}$ & "pain" & $\begin{array}{l}\text { hyalin* } \\
\text { discomfort }\end{array}$ & $\begin{array}{l}\text { "root } \\
\text { resorption" }\end{array}$ \\
\hline Total 3 & $\times 2$ & $\times 2$ & 12 \\
\hline
\end{tabular}

analysis. The bibliometric analysis aimed at identifying the following elements: Author, country of origin, year of publication, journal, and sampling details. In the systematic analysis, besides identifying the evaluated aspects of interest (pain, hyalinization, and/or EARR), it was verified whether the purposes of the articles were in line with the purpose of this present study.

\section{RESULTS}

Flow Chart 1 illustrates the results of the filtering and classification stage. A total of 1,091 studies were retrieved, out of which 719 were duplicate and therefore excluded. Subsequently, 372 studies were selected. As a result of the classification stage, 306 articles were excluded. Moreover, in this stage, it was identified that 25 studies were books and 4 were patents; consequently, they were also discarded. The final portfolio consisted of 37 articles, ${ }^{9-45}$ which were submitted to bibliometric and systematic analysis.

The results of the bibliometric and systematic analyses can be visualized in Table 5. The selected studies were published between 1996 and 2014, 59.46\% being published in 2009. Countries with the highest number of publications were Japan $(35.14 \%$, individually or in collaboration with other countries), Brazil (13.51\%), Germany $(10.81 \%)$, and the United States $(10.81 \%)$. Journals that mostly addressed the analyzed keywords were American Journal of Orthodontics and Dentofacial Orthopedics (21.62\%), European Journal of Orthodontics (18.91\%), and The Angle Orthodontist (13.51\%). As for the sampling, $64.86 \%$ of studies were performed with patients and $27.03 \%$ used rats. In two studies, the interventions were carried out in beagles and in patients $(5.41 \%)$ and in one study, questionnaires were applied to orthodontists $(2.70 \%)$.

Regarding the investigated aspects of interest, $59.46 \%$ of studies evaluated EARR, $18.92 \%$ EARR and pain, $16.22 \%$ pain, $2.70 \%$ hyalinization, and $2.70 \%$ hyalinization and EARR. None of the selected studies aimed at evaluating the correlation between pain and unwanted tissue damage in response to OTM. However, one article ${ }^{39}$

Flow Chart 1: Filtering and classification of articles

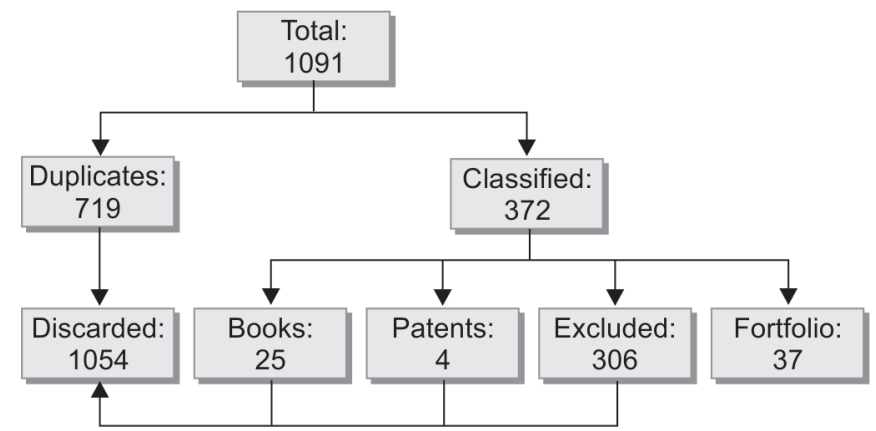




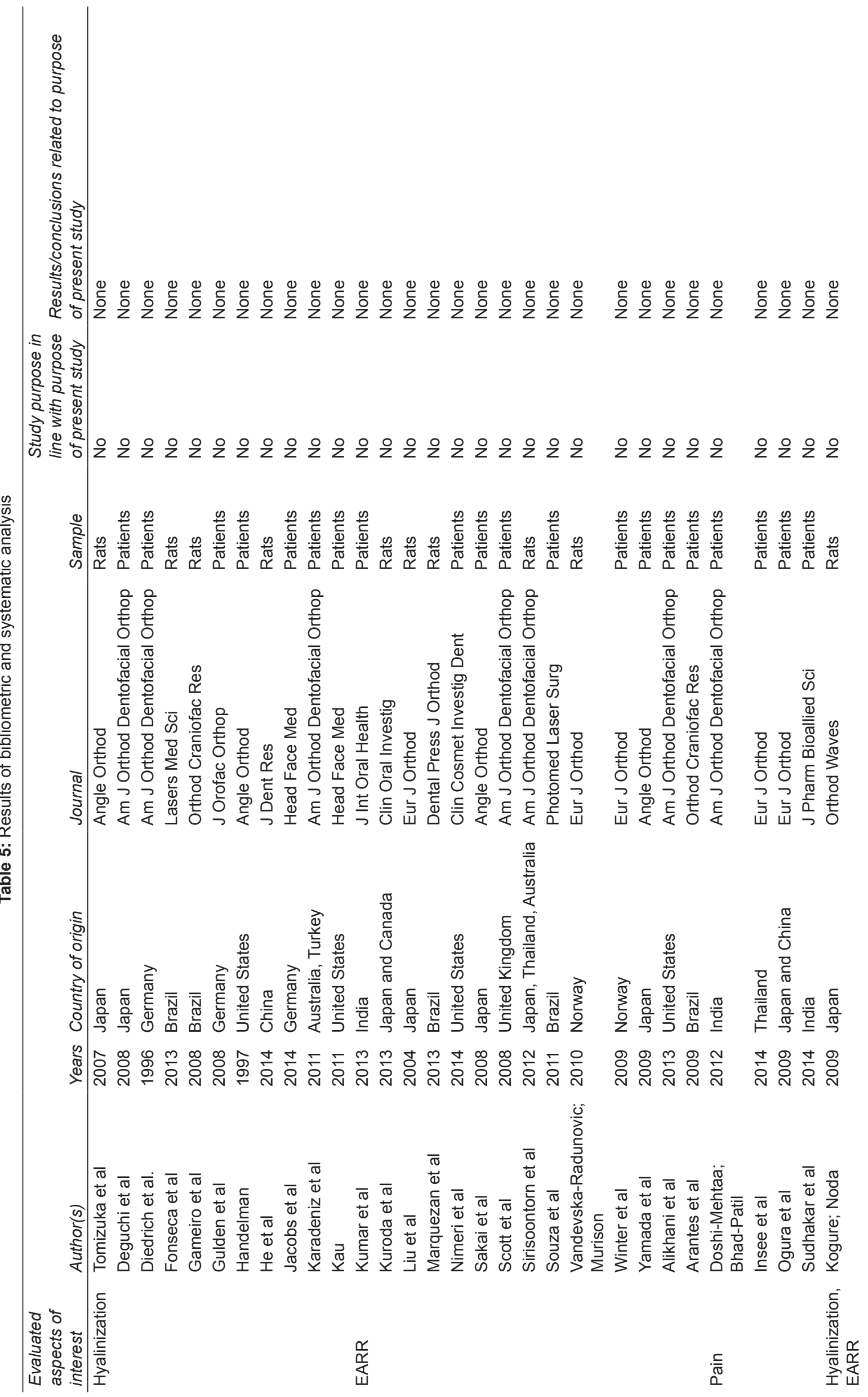


during the first 7 days of the experimental period, the patients were instructed to register the level of pain produced by the procedure in an analogous visual scale. The authors did not observe a correlation between quantity of EARR and pain. Other studies presented results that can be indirectly related to the purposes of the present study. ${ }^{40-43}$ These studies observed that the performed interventions promoted OTM without producing EARR or pain. Villa et $\mathrm{al}^{45}$ reported that the use of medication was efficient in reducing the quantity of EARR and pain after OTM. These studies suggested that there is a correlation between EARR and pain resulting from OTM, since these variables behaved similarly in response to the different interventions.

According to the methodology employed in the present study, the best evidence available in the literature $^{39}$ indicated that there is no correlation between pain and EARR in response to OTM. Nevertheless, this result must be considered with caution, since it is supported by only one study. Additionally, other studies suggested different conclusions. ${ }^{40-43,45}$ Studies on the correlation between pain and hyalinization in response to OTM were not found.

Orthodontic tooth movement is a result of alveolar remodeling through resorption and bone neoformation, as a consequence of inflammation stimulated by the application of mechanical forces, while pain is a characteristic symptom of inflammation. Besides, OTM is related to mechanical stimulation of free nerve endings as a result of application of mechanical forces to teeth. ${ }^{7}$ The incidence of unwanted tissue damage in response to OTM, such as hyalinization of the periodontal ligament and EARR, is directly associated with the use of excessive mechanical force, ${ }^{1,3-5}$ resulting in higher mechanical stimulation of free nerve endings and exacerbation of inflammation.

Although pain and unwanted tissue damage in response to OTM are related to mechanical stimuli and similar biological events, this study showed that the correlation between these variables is not fully elucidated yet. Based on the absence of clinical criteria for the establishment of optimal orthodontic mechanical forces, it is suggested that this issue needs further studies. Thus, orthodontic pain might be used as a clinical parameter to guide the use of biologically appropriate mechanical forces, minimizing the incidence of tissue damage during OTM.

\section{CONCLUSION}

There is not enough scientific evidence on the correlation between pain and unwanted tissue damage in response to OTM. This issue needs further studies, so that orthodontic pain may serve as one of the criteria for the use of biologically appropriate mechanical forces, contributing to reduced tissue damage during OTM.

The current concept of optimal orthodontic force, which is to promote maximum dental movement with minimum tissue damage, is quite subjective and marked by individual variability. In addition, during clinical practice, the orthodontist does not have technological resources or clinical parameters that allow evaluating the intensity of force applied to different areas of the periodontal ligament. One of the common clinical observations related to the application of orthodontic force is the patient report of pain. This article presents a systematic literature review, in which scientific evidence of the correlation between pain and tissue damage during orthodontic movement was studied, providing a scientific answer for the following question: Is pain reported by patients associated with application of inappropriate orthodontic force? Thus, it aims at aiding the orthodontist in the definition of clinical parameters for the use of optimal orthodontic force.

\section{REFERENCES}

1. Krishnan V, Davidovitch Z. Cellular, molecular, and tissuelevel reactions to orthodontic force. Am J Orthod Dentofacial Orthop 2006 Apr;129(4):469.e1-e32.

2. Harris EF. Root resorption during orthodontic therapy. Semin Orthod 2000 Sep;6(3):183-194.

3. Brezniak N, Wasserstein A. Root resorption after orthodontic treatment: part 1. Literature review. Am J Orthod Dentofacial Orthop 1993 Jan;103(1):62-66.

4. Maltha JC, van Leeuwen EJ, Dijkman GE, Kuijpers-Jagtman AM. Incidence and severity of root resorption in orthodontically moved premolars in dogs. Orthod Craniofac Res 2004 May;7(2):115-121.

5. Weltman B, Vig KW, Fields HW, Shanker S, Kaizar EE. Root resorption associated with orthodontic tooth movement: a systematic review. Am J Orthod Dentofacial Orthop 2010 Apr;137(4):462-476.

6. Ren Y, Maltha JC, Kuijpers-Jagtman AM. Optimum force magnitude for orthodontic tooth movement: a systematic literature review. Angle Orthod 2003 Feb;73(1):86-92.

7. Krishnan V. Orthodontic pain: from causes to management-a review. Eur J Orthod 2007 Apr;29(2):170-179.

8. Marafon AD, Ensslin L, Ensslin SR, Lacerda RT. Revisão sistêmica da literatura internacional sobre avaliação de desempenho na gestão de P\&D. Revista Gestão Industrial 2012;8(3):1-43.

9. Tomizuka R, Shimizu Y, Kanetaka H, Suzuki A, Urayama S, Kikuchi M, Mitani H, Igarashi K. Histological evaluation of the effects of initially light and gradually increasing force on orthodontic tooth movement. Angle Orthod 2007 May; 77(3):410-416.

10. Deguchi T, Murakami T, Kuroda S, Yabuuchi T, Kamioka H, Takano-Yamamoto T. Comparison of the intrusion effects on the maxillary incisors between implant anchorage and 
J-hook headgear. Am J Orthod Dentofacial Orthop 2008 May;133(5):654-660.

11. Diedrich PR, Fuhrmann RA, Wehrbein H, Erpenstein H. Distal movement of premolars to provide posterior abutments for missing molars. Am J Orthod Dentofacial Orthop 1996 Apr;109(4):355-360.

12. Fonseca PD, Lima FM, Higashi DT, Koyama DF, Toginho Filho DO, Dias IF, Ramos Sde P. Effects of light emitting diode (LED) therapy at $940 \mathrm{~nm}$ on inflammatory root resorption in rats. Lasers Med Sci 2013 Jan;28(1):49-55.

13. Gameiro GH, Nouer DF, Pereira-Neto JS, Magnani MBA, Andrade ED, Novaes PD, de Arruda Veiga MC. Histological analysis of orthodontic root resorption in rats treated with the cyclooxygenase-2 (COX-2) inhibitor celecoxib. Orthod Craniofac Res 2008 Aug;11(3):156-161.

14. Gülden N, Eggermann T, Zerres K, Beer M, Meinelt A, Diedrich P. Interleukin-1 polymorphisms in relation to external apical root resorption (EARR). J Orofac Orthop 2009 Jan;70(1):20-38.

15. Handelman CS. Nonsurgical rapid maxillary alveolar expansion in adults: a clinical evaluation. Angle Orthod 1997;67(4):291-305.

16. He D, Kou X, Luo Q, Yang R, Liu D, Wang X, Song $Y$, Cao H, Zeng M, Gan Y, et al. Enhanced M1/M2 macrophage ratio promotes orthodontic root resorption. J Dent Res 2015 Jan;94(1):129-139.

17. Jacobs C, Gebhardt PF, Jacobs V, Hechtner M, Meila D, Wehrbein $\mathrm{H}$. Root resorption, treatment time and extraction rate during orthodontic treatment with self-ligating and conventional brackets. Head Face Med 2014 Jan;10(2):1-7.

18. Karadeniz EI, Gonzales C, Nebioglu-Dalci O, Dwarte D, Turk T, Isci D, Sahin-Saglam AM, Alkis H, Elekdag-Turk S, Darendeliler MA. Physical properties of root cementum: part 20. Effect of fluoride on orthodontically induced root resorption with light and heavy orthodontic forces for 4 weeks: a microcomputed tomography study. Am J Orthod Dentofacial Orthop 2011 Nov;140(5):e199-e210.

19. Kau CH. A radiographic analysis of tooth morphology following the use of a novel cyclical force device in orthodontics. Head Face Med 2011 Aug;7(14):1-5.

20. Kumar N, Prashantha G, Raikar S, Ranganath K, Mathew S, Nambiar S. Dento-alveolar distraction osteogenesis for rapid orthodontic canine retraction. J Int Oral Health 2013 Dec;5(6): $31-41$.

21. Kuroda S, Wazen R, Moffatt P, Tanaka E, Nanci A. Mechanical stress induces bone formation in the maxillary sinus in a short-term mouse model. Clin Oral Investig 2013 Jan;17(1): 131-137.

22. Liu L, Igarashi K, Haruyama N, Saeki S, Shinoda H, Mitani H. Effects of local administration of clodronate on orthodontic tooth movement and root resorption in rats. Eur J Orthod 2004 Oct;26(5):469-473.

23. Marquezan M, Bolognese AM, Araújo MT. Evaluation of two protocols for low-level laser application in patients submitted to orthodontic treatment. Dental Press J Orthod 2013 Feb;18(1):33.e1-e9.

24. Nimeri G, Kau CH, Corona R, Shelly J. The effect of photobiomodulation on root resorption during orthodontic treatment. Clin Cosmet Investig Dent 2014 Jan;6:1-8.

25. Sakai Y, Kuroda S, Murshid SA, Takano-Yamamoto T. Skeletal Class 111 severe openbite treatment using implant anchorage. Angle Orthod 2008 Jan;78(1):157-166.
26. Scott P, DiBiase AT, Sherriff M, Cobourne MT. Alignment efficiency of Damon3 self-ligating and conventional orthodontic bracket systems: a randomized clinical trial. Am J Orthod Dentofacial Orthop 2008 Oct;134(4):470.e1-e8.

27. Sirisoontorn I, Hotokezaka H, Hashimoto M. Orthodontic tooth movement and root resorption in ovariectomized rats treated by systemic administration of zoledronic acid. Am J Orthod Dentofacial Orthop 2012 May;141(5):563-573.

28. Sousa MV, Scanavini MA, Sannomiya EK, Velasco LG, Angelieri F. Influence of low-level laser on the speed of orthodontic movement. Photomed Laser Surg 2011 Mar;29(3): 191-196.

29. Vandevska-Radunovic V, Murison R. Emotional stress and orthodontic tooth movement: effects on apical root resorption, tooth movement, and dental tissue expression of interleukin-1 alpha and calcitonin gene-related peptide immunoreactive nerve fibres in rats. Eur J Orthod 2010 Jun;32(3):329-335.

30. Winter BU, Stenvik A, Vandevska-Radunovic V. Dynamics of orthodontic root resorption and repair in human premolars: a light microscopy study. Eur J Orthod 2009 Aug;31(4): 346-351.

31. Yamada K, Kuroda S, Deguchi T, Takano-Yamamoto T, Yamashiro T. Distal movement of maxillary molars using miniscrew anchorage in the buccal interradicular region. Angle Orthod 2009 Jan;79(1):78-84.

32. Alikhani M, Raptis M, Zoldan B. Effect of micro-osteoperforations on the rate of tooth movement. Am J Orthod Dentofacial Orthop 2013 Nov;144(5):639-648.

33. Arantes GM, Arantes VM, Ashmawi HA, Posso IP. Tenoxicam controls pain without altering orthodontic movement of maxillary canines. Orthod Craniofac Res 2009 Feb;12(1):14-19.

34. Doshi-Mehta G, Bhad-Patil WA. Efficacy of low-intensity laser therapy in reducing treatment time and orthodontic pain: a clinical investigation. Am J Orthod Dentofacial Orthop 2012 Mar;141(3):289-297.

35. Insee K, Pothacharoen P, Kongtawelert P, Ongchai S, Jotikasthira D, Krisanaprakornkit S. Comparisons of the chondroitin sulphate levels in orthodontically moved canines and the clinical outcomes between two different force magnitudes. Eur J Orthod 2014 Feb;36(1):39-46.

36. Ogura M, Kamimura H, Al-Kalaly A, Nagayama K, Taira K, Nagata J, Miyawaki S. Pain intensity during the first 7 days following the application of light and heavy continuous forces. Eur J Orthod 2009 Jun;31(3):314-319.

37. Sudhakar V, Vinodhini TS, Mohan AM, Srinivasan B, Rajkumar BK. The efficacy of different pre- and post-operative analgesics in the management of pain after orthodontic separator placement: a randomized clinical trial. J Pharm Bioallied Sci 2014 Jul;6(Suppl 1):S80-S84.

38. Kogure K, Noda K. Periodontal response to experimental tooth movement by interrupted orthodontic force in rats. Orthod Waves 2009 Sep;68(3):97-106.

39. Cakmak F, Turk T, Karadeniz EI, Elekdag-Turk S, Darendeliler MA. Physical properties of root cementum: part 24. Root resorption of the first premolars after 4 weeks of occlusal trauma. Am J Orthod Dentofacial Orthop 2014 May;145(5):617-625.

40. Mandall N, Lowe C, Worthington H, Sandler J, Derwent S, Abdi-Oskouei M, Ward S. Which orthodontic archwire sequence? A randomized clinical trial. Eur J Orthod 2006 Dec;28(6):561-566. 
41. Moon $\mathrm{CH}$, Wee JU, Lee HS. Intrusion of overerupted molars by corticotomy and orthodontic skeletal anchorage. Angle Orthod 2007 Nov;77(6):1119-1125.

42. Noda K, Nakamura Y, Oikawa T, Hirashita A. Tooth movement limited to periodontal ligament width using interrupted orthodontic force. Orthod Waves 2006 Jun;65(2):73-80.

43. Noda K, Nakamura Y, Oikawa T, Shimpo S, Kogure K, Hirashita A. A new idea and method of tooth movement using a ratchet bracket. Eur J Orthod 2007 Jun;29(3):225-231.
44. Schuster G, Borel-Scherf I, Schopf PM. Frequency of and complications in the use of RPE appliances - results of a survey in the Federal State of Hesse, Germany. J Orofac Orthop 2005 Mar;66(2):148-161.

45. Villa PA, Oberti G, Moncada CA, Vasseur O, Jaramillo A, Tobón D, Agudelo JA Pulp-dentin complex changes and root resorption during intrusive orthodontic tooth movement in patients prescribed nabumetone. J Endod 2005 Jan;31(1): 61-66. 